\title{
School Dropout (Case Study of Farmers Children in Tounsaru District of South Tondano Minahasa Regency)
}

\author{
${ }^{1}$ Zoni Henki Singal* \\ Sociology Educational Department \\ Social Science Faculty \\ Universitas Negeri Manado \\ Tondano, Indonesia \\ Zoni-Henki@yahoo.co.id
}

\author{
${ }^{2}$ Nismawati \\ Sociology Educational Department \\ Social Science Faculty \\ Universitas Negeri Manado \\ Manado, Sulawesi Utara \\ nismaimma019@gmail.com
}

\author{
${ }^{3}$ Maryam Lamadirisi \\ Department of Sociology Educattion \\ Social Science Faculty \\ Universitas Negeri Manado \\ Tondano, Indonesia \\ maryamlamadiris@unima.ac.id
}

\begin{abstract}
This study aims to determine the background dropout and the social role in helping the family economy in Tounsaru, District of South Tondano, Minahasa Regency. The approach used in this research is qualitative descriptive type. Research informants are 12 people were selected using purposive sampling techniques. Data collection conducted by observation, interviews, and documentation and then analyzed descriptively through three stages, namely: (1) reducing data, (2) presenting data in the form of brief descriptions, and (3) drawing conclusions to answer the problem formulation. The results showed: (1) School dropouts in Tounsaru were mostly caused by economics, then followed by the low interest of children, low parental attention, culture, and the distance between home and school; (2) The social role of children in helping the family economy is helping parents work in the fields and doing other work to fulfill needs of the family.
\end{abstract}

Keywords: Dropout, Case Study

\section{INTRODUCTION}

The community is a social group whose unit consists of several families. "The family is seen as the core of the smallest social group of society formed by marriage and a family consisting of a husband (father), wife (mother) and children". "Children are the next generation for the survival of families, and nations in the future. Therefore, providing guarantees for future generations to be able to grow and develop properly is a social investment of the future is not easy and must be borne by the family, community, and country" [1].

Education is a means of an effort to develop the potential of children who will become the next generation of families as well as the nation and state generation. "The essence of education is to humanize human beings, which is a process sees humans as a whole in their existence". This understanding implies the existence of talents and potential in children is explored through the educational process. Education is also interpreted as "a process takes place in life as an effort to balance the conditions inside themselves. This balancing process is a form of survival conducted anyone can participate in every activity takes place" [2].

The success of the education system requires public awareness to be educated. However, this awareness is increasingly reduced by the emergence of the assumption is the point of high school if ultimately not have a job. The large number of formal education graduates ranging from junior high school to unemployed college graduates have harmed people's perceptions about the importance of education for children. Such conditions lead to the reluctance of parents to continue their children's education, thereby increasing the number of children who have dropped out of school.

Dropping out of school is a "predicate given to former students who are unable to complete an education level, so they cannot continue their studies to the next level of education. For example, a community member or child who only attends elementary school until the fifth grade is called an elementary school dropout ".

School dropouts are caused by a variety of factors. Several factors affect school dropouts, namely: "economic status, type of student education (general or vocational), pregnancy, poverty, discomfort, student delinquency, illness, interests, traditions/customs, parental education, parental occupation, parental age, number of family dependents, living conditions and parents' attention. "

The government has tried to overcome the problem of dropping out of school by providing a School Operational Assistance Program (BOS). The purpose of this program is to free up the cost of education for underprivileged students and ease other students so that they obtain higher quality basic education services to graduate in the context of completing the 9 -year compulsory education. Although government efforts have been made, there are still cases of children dropping out of school.

The results of preliminary observations made by the author indicate some people in Tounsaru, South Tondano Subdistrict, Minahasa Regency have a view that education is not a solution in improving living standards, sometimes children who take a role in helping the family economy. The tendency of the community's views comes from the farming community. Children in farming families tend to help and manage agricultural land to support the family's economy, these activities often prevent them from attending school lessons.

Based on the description, an in-depth study was conducted to find out the background of children who have dropped out of school and the social role of dropouts in helping the family economy in Tounsaru, District of South Tondano, Minahasa Regency. 


\section{METHODS}

This research is a qualitative descriptive type. "Qualitative research is a study intended to describe and analyze phenomena, events, social activities, attitudes, beliefs, perceptions, thoughts of individuals or groups". This research was conducted in Tounsaru, South Tondano District, Minahasa Regency. Research informants are 12 people were selected using purposive sampling techniques. Data in this study were collected using the method of observation, interviews, and documentation. The data analysis technique used is descriptive qualitative which is divided into three stages, namely (1) data reduction, (2) data presentation, and (3) concluding [3]. The data waving technique used is a member check. A member check is a process of checking data obtained by researchers to the data giver. The purpose of the member check is the information obtained and will be used in writing the report according to the data source or informant [4].

\section{RESULTS AND DISCUSSION}

\section{Background of Farmers' Children Dropping Out of School}

Findings from the results of research conducted discussing dropping out of school are known as the background of farmers dropping out of school is due to the problem of lack of funds, their culture, and lack of importance in education. Many children dropping out of school in Tounsaru thinking that schools can only read and write enough. Considering the ability to read and write has been achieved in grades 3 or 4, parents sometimes have assumed that their children do not need to go to school until graduating from elementary school. Especially if you remember the working conditions in the area. The ability to produce between those who have graduated from elementary school and those who have only reached grades 3 or 4 for example. Naturally, the evidence shows some parents who are unable to continue their children's education to secondary school, believe there is no point in issuing costs for higher education.

Dropping out of school in Tounsaru is not only an educational problem but also a social and economic problem. Various socio-economic (as well as cultural) factors can influence the level of drop-out rate. Besides, dropping out of school seems to be somewhat veiled, because they are directly utilized by the agricultural sector, they immediately become family workers. If they are bored with this field or indeed in the area, there is no other job, then they tend to go to the city to look for work. They work as jobless work as a day laborer, construction worker, canteen and others. Dropping out of school for farming families, not only comes from poor farmers who cannot afford but not infrequently comes from families of middle farmers. This is mostly caused by economic factors. From a variety of choices, humans are moral should choose "a way to climb" is difficult for the climber, due to sacrifice is needed an effort to free people from hunger, poverty, and decline in their dignity.
An explanation from one of the informants revealed the reason for his dismissal or not completing his child's education was due to his ability to pay for his children's schooling. This sufficient evidence is not because parents do not want to send their children to school but the enthusiasm or desire of these parents remains should be stopped due to constraints on financing issues. Furthermore, the informant emphasized to the researchers although the government had set up a free education program, it was indeed quite helpful in the issue of payment of tuition fees or book buyers, but with the existence of the program it would not be the most effective solution would eradicate the dropout phenomenon in Tounsaru, South Tondano District.

As stated by reference [5]: poverty has a pluralistic nature, poverty shows the existence of a group of completely lacking people. It is proven that although this free education program is already in effect in the Minahasa District, many children are still of school age but are no longer in school. Most of the Tounsaru community considered the school was only for how a child could read and write. Some students did drop out of school because they were stopped by their parents with the paradigm that a child would be more useful when he quit school and worked in the fields to help parents and family income.

The majority of people in Tounsaru work as seasonal farmers who only rely on rain-fed water to manage their fields, due to there is no irrigation for the residents, farmers can only plant rice in one season, which is the rainy season. This will be more convincing than the income of farmers in the area. Some of the residents who became informants in this study generally shared the same opinion when asked their opinion about the phenomenon of dropping out of school in their community, which we can understand they shared the same understanding of poverty was the main cause of the many children who dropped out of school, informant clearly said people who only work as farmers could not do much to send their children to school due to they were not even able to pay for school fees, especially their rice plants were attacked by pests causing harvest failure. From the affirmation of several informants, the researcher can explain the causative factor for dropping out of school in Tounsaru, South Tondano District, Minahasa Regency is poverty.

\section{Form the Social Role of Children in Helping the Family Economy}

In families with limited economic levels, the presence of children conducts certain work to supplement household/family income. Besides, he was banned from school for the sake of earning a living. These conditions indicate the role of children is limited to earning a living and helping the family economy without regard to other aspects. For example, the level of education and patterns of community relations, where the child is given a burden to help parents in making money and take care of the household. "Social role is a way or actions of an individual an effort to fulfill the responsibilities of the rights of social status, then someone involved in conducting 
or not activities that according to their social status. This can be seen from the role of different individuals at once in the same social status ".

It can be said that children have a very important role in improving the socioeconomic status of the family by helping to increase family income. Think carefully, the socioeconomic status of a family is not only judged by economic income but is related to the pattern of its relationship with the community. In the farming community, children not only play a role in helping parents to work on the fields/gardens as a source of basic family livelihood, but children must play a role in making parents develop mindset according to the development of the times and the knowledge.

Children are motivated to help the family due to the conditions of our needs are increasing, which used to only meet basic needs, now in other needs sometimes inevitably have to be met, this is inseparable from the influence of the media offering things make people consumed by media, lifestyle. The main child meets his own needs, due to parents cannot meet the needs of the child takes the initiative to look for his own needs, in that case, the child can help his parents.

In general, children in farming families have tended to help in managing their agricultural land, generally, farmers work in the fields with a planting system is done generally twice a year, of all people sometimes teach their children from an early age to help in the fields with the hope of light work and get results abundant agriculture. Children in farm families help in planting or harvesting seasons, maintenance of fertilizer while waiting for the results is the work of parents.

In the interim activities, while waiting for the results of the management of the crop at the time many children look for other work, for children who do not go to school, they can earn income to help alleviate the needs of the family. Began to raise animals such as chickens, cows, goats, and horses, for side jobs that are not so binding, such as being a laborer. The role of school children is very visible in Tounsaru, South Tondano Sub-district, as evidenced by the daily activities conducted by children who drop out of school to help parents work from homework, helping parents in the fields or becoming unskilled laborers.

\section{CONCLUSION}

Based on the results of the study and discussion, it was concluded that: (1) School dropouts in Tounsaru are mostly caused by economics, then followed by the low interest of children, low parental attention, culture, and distance between home and school; (2) The social role of children in helping the family economy is helping parents work in the fields and doing other work in hopes to complete the economic needs of the family. This result implies the future more in-depth research related to school dropouts in terms of and other locations.

\section{REFERENCES}

[1] S. Soekanto, Sosiologi suatu pengantar. Jakarta: Raja Grafindo Persada, 2012.

[2] H. A. R. Tilaar, Perubahan Sosial dan Pendidikan. Jakarta: Gramedia, 2002.

[3] M. B. Miles and A. M. Huberman, 'Analisis data Kualitatif: Buku Sumber Tentang Metode-metode Penelitian Baru', Terjemahan. UI-Press: Jakarta, 1992.

[4] L. J. Moleong, Metodologi Penelitian Kualitatif. Bandung: Remaja Rosdakarya, 2011.

[5] L. Hikmah, H. Quraisy, and J. Arifin, 'Kemiskinan Dan Putus Sekolah', J. Equilib. Pendidik. Sosiol., vol. 4, no. 2,2016 